\title{
EFFECT OF ANTIMELANOTIC TREATMENT AND VACUUM PACKAGING ON MELANOSIS AND QUALITY CONDITION OF ICE STORED FARMED TIGER SHRIMP (Penaeus monodon)
}

\author{
Vijay Kumar Reddy. S*, Pradnya A. Shinde, Faisal R. Sofi ${ }^{1}$, \\ Piyusha S. Shelar ${ }^{2}$ and S. B. Patange \\ Department of Fish Processing Technology and Microbiology, Fisheries College, Shirgaon, Ratnagiri, \\ Maharashtra, India - 415629
}

\begin{abstract}
The objective of the study was to evaluate the effect of vacuum packaging in combination with antimelanotic treatment on quality characteristics and melanosis in farmed tiger shrimp (Penaeus monodon) collected from Ratnagiri region of Maharashtra. The processed shrimps were treated with sulfite mixture in water $\left(30 \mathrm{~g} \mathrm{~kg}^{-1}\right)$ and divided into two lots each with 250 shrimps. One of them was vacuum packed, the other was air packed and stored under ice. The ice stored shrimps were analyzed for quality attributes and melanosis for a period of 27 days. The treated vacuum packed shrimps had a shelf life of 24 days, whereas air packed shrimp had 16 days only. Melanosis was absent in the shrimps from both the lots throughout the storage period. Based on the results, it could be concluded that the combination of antimelanotic treatment (sulphite mixture) and packaging could significantly delay the occurrence of melanosis and increase the storage life of shrimp in ice.
\end{abstract}

Key words: Tiger shrimp, antimelanotic treatment, melanosis, Sodium metabisulphite, treated air packed, treated vacuum packed

\section{Practical applications}

In farmers practice Penaeus monodon will be treated with sodium metabisulphite of high concentrations immediately after the capture to prevent melanosis and for keeping quality. Even after the treatment, the shrimps deteriorate

\footnotetext{
*Corresponding author email: bhajarangbhali@gmail.com

${ }^{1}$ Ph.D. Student, Department of Fish Processing Technology, College of Fisheries, KVAFSU, Mangalore, Karnataka, India-575001

${ }^{2}$ Deptt. Aquatic Environment and Management, Fisheries College and Research Institute, TANVASU, Tuticorin,

Tamil Nadu
}

Received: 14.10.2012 
rapidly and show melanosis within few hours and may also contain high sulphite residues, which is not desirable. In order to overcome these problems, the tiger shrimp were treated with sulphites of low concentration, than that used in regular farmers practice and was combined with packaging to create more period of contact to get more effect of metabisulphite and to prevent reaction of food with oxygen. The combined effect of packaging and sulphite treatment could delay the occurrence of melanosis and can keep the quality of shrimps for a long period (up to 27 days), which is only few days i.e., 2-8 days in case without treatment and packaging. So the work done is very much useful to farmers as well as processors to maintain the edibility of shrimp for longer periods.

\section{INTRODUCTION}

Shrimp continues to be the most important commodity traded in value terms, accounting for 15.4 per cent of the total value of internationally traded fish products (FAO, 2009). Demand for shrimp is increasing at a rapid rate. During 2008-09, shrimp continued to be the major item contributing more than $50 \%$ in value of total export of marine products from India (MPEDA, 2010). Shrimp is more susceptible to spoilage from postmortem autolysis and microbial growth. The high ambient temperature of our country favours rapid growth of microorganisms. There are several methods to preserve fresh fish and shrimp. Icing is a common method for short-term preservation.

The appearance of melanosis or blackspots on prawn, shrimp, and other fresh or raw crustaceans is rapid, even in chilled storage, and involves some important economic losses for the fish industry. One of the cheapest, easiest and most efficient methods of preventing blackspot is the use of sulfites (Smith, 1980). In several studies it was reported that sodium metabisulfite extended the melanosis for considerable periods (Chakrabarti and Gupta, 1998; Chakrabarti et al., 1992; GomezGuillen et al., 2005; Martinez-Alvarez et al., 2005; Ogawa, 1987 and Smith, 1980).To promote the marketing of fresh fishery products at retail level, novel methods of packaging and storage are required. One such method of current interest is vacuum packaging. Studies have shown that vacuum packaging in combination with lower temperatures improves the shelf life considerably (Jeyasekaran et al., 2004; Lopez-Caballero et al., 2000; Perez-Alonso et al., 2004; Rajesh et al., 2002 and Shalini et al., 2000).

The black tiger shrimp Penaeus monodon, is the most important aquacultured shrimp species in the world, accounting for $46 \%$ of the total aquaculture shrimp (Hanpongkittikun et al., 1995). Penaeus monodon locally known as 'Tiger kolambi' is one of the most important cultivable species along the entire coast of India. Demand for fresh farmed tiger shrimp is very high and storage life in ice is limited. No literature is available on using of combination of vacuum packaging with antimelanotic treatment for prevention of the quality changes in shrimp. The present 
study was therefore undertaken to find out the effect of the combination of antimelanotic treatment and vacuum packaging on the storage characteristics of farmed tiger shrimp in ice, especially on occurrence of melanosis and shelf life.

\section{MATERIALS AND METHODS}

\section{Harvesting and Treatment of Raw Material}

Fresh tiger shrimp, Penaeus monodon procured from 'Zadgaon brackish water shrimp farm, Ratnagiri, Maharashtra State, India, were brought to the laboratory in iced condition. The time period from the harvest of shrimps to testing was four hours. The shrimps used for this study had an average weight and average total length of $25 \pm 5 \mathrm{~g}$ and $15 \pm 2 \mathrm{~cm}$ respectively. The shrimps were processed to remove rostrum and telson and were given dip treatment in seawater at 1:2 ratio (Shrimp to Sea water) containing sodium metabisulfite, citric acid, ethylene di-amine tetra acetic acid and disodium dihydrogen pyrophosphate at the concentrations of $30 \mathrm{~g}, 20 \mathrm{~g}$, $0.45 \mathrm{~g}$ and $30 \mathrm{~g}$ for every kilogram of shrimp treated in every 2 liters of sea water (Gomez-Guillen et al., 2005). The sulfite treated shrimp were divided into two lots-1) treated vacuum packed (TVP): The shrimps were treated with $30 \mathrm{~g} \mathrm{~kg}^{-1}$ sulfites and then vacuum-packed. 2) Treated Air Packed (TAP): The shrimps were treated with $30 \mathrm{~g} \mathrm{~kg}^{-1}$ sulfites and then packed without vacuum (air pack).

\section{Packing and storage of treated shrimp}

The treated shrimps were packed in laminate pouches of $12 \mu \mathrm{m}$ polyester and 300 guage polyethylenes Lot I was vacuum packed at -1 bar pressure. Vacuum packaging machine (Dong Bang Machineries Pvt. Ltd., China) was used for packaging of whole tiger shrimps. The physical properties of the packaging materials used are given in table 1. Immediately after packing, all the packs were iced with flake ice in the ratio of 1:1 (shrimp to ice) in an insulated box. The insulated box was kept in a cold room maintained at $0-4^{\circ} \mathrm{C}$. Re-icing was done every day to supplement the loss due to melting, after draining the melted ice.

\section{Quality analysis during period of ice storage}

Samples in triplicate were drawn from each lot at regular intervals of $24 \mathrm{hrs}$ for analysis throughout the storage period of 27 days and the average results are presented. All the packs were analysed for sensory, microbiological (Total Plate Count (TPC), Staphylococcus aureus, Psychrotrophic count, anaerobic count) and biochemical parameters ( $\mathrm{pH}, \mathrm{TMA}-\mathrm{N}, \mathrm{TVB}-\mathrm{N}$, AAN and FFA).

Moisture, crude protein, fat and ash were determined according to the methods described in AOAC (2000). The moisture content was measured by drying in a hot air oven (Kumar sales corporation, Mumbai), maintained at $100{ }^{\circ} \mathrm{C} \pm 2{ }^{0} \mathrm{C}$ for $16-18$ hours. The weight loss was expressed as percent moisture content of the meat. The protein content was determined by estimating total nitrogen in the sample using Kelplus electrically heating digestion and distillation unit (Pelican Equipment, 
Chennai). Crude protein content was calculated by multiplying total nitrogen content by 6.25 and expressed as percentage weight of meat.

The crude fat content of the meat was determined using SOCS plus unit (Pelican Equipment, Chennai). The fat present in the sample was extracted by using petroleum ether (AR grade). Then it was dried initially on a water bath at $98^{\circ} \mathrm{C}-$ $100^{\circ} \mathrm{C}$ and then in an oven at $60^{\circ} \mathrm{C} \pm 5^{\circ} \mathrm{C}$. The difference in the initial and final weight of receiver beaker was determined and fat content of meat was calculated on wet weight basis. In ash content determination preliminary ashing was done by slow heating on a flame to allow smoking off fat without burning. Once the smoke stopped evolving from sample, it was incinerated in a muffle furnace (Cintex, Mumbai) at $550{ }^{\circ} \mathrm{C} \pm 10{ }^{\circ} \mathrm{C}$ for 5 hours until a white ash resulted. The $\mathrm{pH}$ of the sample was determined with a pHm93 pH-meter and a combined $\mathrm{pH}$ electrode (Radiometer, Copenhagen, Denmark).

The Free Fatty Acid (FFA) content in the lipid extract was determined with improved titremetric method as described by (AOAC, 2000). Methanol and isopropanol (chloroform: methanol: Isopropanol $=2: 1: 2$ ) were added to chloroform extract. The extract was titrated with $\mathrm{NaOH}$ using metacresol purple as an indicator. The percentage of free fatty acid was calculated as oleic acid percentage.

Total volatile base nitrogen (TVB-N) and trimethyl amine nitrogen (TMA-N) were determined using a micro diffusion method (Conway, 1950). A1 ml of sulphuric acid was added to inner chamber of the diffusion unit and $1 \mathrm{ml}$ of muscle solution which was extracted with TCA was added followed by addition of $1 \mathrm{ml}$ of saturated potassium carbonate. The unit was sealed and kept undisturbed overnight. The amount of unreacted acid in the inner chamber was determined by titrating against standard sodium hydroxide with Tashiro's indictor. TVB-N was calculated and expressed in mg $100 \mathrm{~g}^{-1}$ of the sample. The TMA was determined following the method used for TVB-N estimation, except the addition of neutral formaldehyde to the outer chamber for TMA-N estimation. TMA-N was calculated as explained in

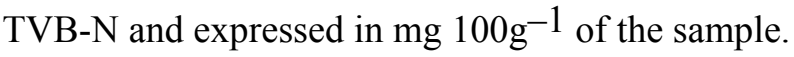

Determination of $\alpha$-amino nitrogen (AAN) content was done according to the method given by Benjakul and Morrissey, 1997. The sample was extracted with TCA and then added with few drops of thymolpthalein and $\mathrm{NaOH}$. Then $10 \mathrm{ml}$ of this was added to $30 \mathrm{ml}$ mixed solution of $\mathrm{Cucl}_{2}$, tri-sodium phosphate and borate buffer (1:2: 2). A $10 \mathrm{ml}$ of the filtrate is added with $0.5 \mathrm{ml}$ of glacial acetic acid and $0.5 \mathrm{~g}$ of potassium iodide. The liberated iodine was titrated against sodium thiosulphate using starch as an indicator, when yellow solution of Iodine became faint yellow, few drops of starch solution was added and titration was continued till blue color disappeared. AAN was calculated as $\mathrm{mg} 100 \mathrm{~g}^{-1}$ of muscle.

The total plate count, S. aureus, psychrotrophic count and anaerobic count were carried out for all the lots throughout storage period by using the method given 
by Tomlinson (1995). For estimating total plate count, appropriate dilutions were prepared from the homogenate using physiological saline and placed on plate count agar by pour plate method. The petri dishes were incubated at $37^{\circ} \mathrm{C}$ for $24-48 \mathrm{~h}$. The colonies developed on agar plates were counted and expressed as $\mathrm{cfu}^{-1}$. In case of psychrotrophic count estimation, the petri dishes were pour plated and incubated at $7 \pm 1^{\circ} \mathrm{C}$ for 7-8 days. The colonies developed on agar plates were counted and expressed as cfu $\mathrm{g}^{-1}$.

For determining staphylococcal count, the petri dishes were plated by spread plate method on Baired parker agar. The plates were incubated at $37^{\circ} \mathrm{C}$ for $48 \mathrm{~h}$. the colonies of $S$. aureus were expressed as $\mathrm{cfu}^{-1}$. Total anaerobes were determined by 3 tube MPN technique. The sample was inoculated with $10 \mathrm{ml}$ each into 3 tubes of 10 $\mathrm{ml}$ thioglycollate broth, $1 \mathrm{ml}$ each to 3 tubes of thioglycollate broth and $0.1 \mathrm{ml}$ of each to 3 tubes of thioglycollate broth. The test tubes were overlaid with sterile paraffin oil and incubated at $35^{\circ} \mathrm{C}$ for 48 hours. The probable number of anaerobic count were calculated according to the various combinations of +ve and -ve reactions by using Mac crady table.

Sensory evaluation was done by a 10 point scoring system using a modified version of one developed by Peryam and Pligirms (1957) based on characterization and differentiation of the various sensory characters, such as appearance, texture, odour and flavor. Scores were given by five trained panelists, based on a ten-point hedonic scale. Score 5 was taken as the borderline of acceptability. Evaluation for Melanosis was done by a 4 point scoring system, a modified version used by GomezGuillen et al. (2005) for Parapenaeus longirostris. Low score indicated less melanosis, good quality and vice versa.

\section{RESULTS AND DISCUSSION}

\section{Raw material characteristics}

The proximate composition of fresh farmed tiger shrimp is given in figure 1 . The proximate composition analysed was $75.16 \%$ moisture, $1.98 \%$ crude fat, $21.07 \%$ crude protein and $1.79 \%$ crude ash. There were no significant differences found in the proximate composition with increased storage period. Initial sensory, chemical and bacteriological analysis of fresh tiger shrimp indicated that the quality of the raw material was very fresh. The fresh tiger shrimp used in the present study had $\mathrm{pH}$, TMA-N, TVB-N, AAN and indole values of $6.58,8.92 \mathrm{mg} \%, 0.34 \mathrm{mg} \%, 18.46 \mathrm{mg} \%$ and $4 \mu \mathrm{g} / 100 \mathrm{~g}$ respectively. It was reported that the raw tiger shrimp used in their study had TMA-N, TVB-N and indole content of 3.78-7.28 mg\%, $15.96-28.28$ $\mathrm{mg} \%$, and $5.85-6.85 \mu \mathrm{g} / 100 \mathrm{~g}$ respectively (Antony et al., 2002). The fresh tiger shrimp used in another study had $\mathrm{pH}$ and TVB-N values of 6.63 and $5.88 \mathrm{mg} \%$ (Rahaman et al., 2001).

The fresh tiger shrimp used in present study had TPC and psychrotrophic counts of $4.08 \mathrm{log} \mathrm{cfu} / \mathrm{g}$ and $4.02 \mathrm{log} \mathrm{cfu} / \mathrm{g}$. Anaerobes and Staphylococcus were not detected in fresh shrimp. 


\section{Changes in bio-chemical characteristics during ice storage}

The TMA-N content, which indicates the extent of protein breakdown, usually caused by bacteria or enzymes, increased gradually in all the samples with storage time, as observed by earlier authors (Figure 2). In the present work, the initial TMA$\mathrm{N}$ value was $0.34 \mathrm{mg} \%$, which increased to $3.26 \mathrm{mg} \%$, and $2.44 \mathrm{mg} \%$ for the TAP and TVP samples respectively on the $8^{\text {th }}$ of day storage. The TMA-N further gradually increased up to $17^{\text {th }}$ day of storage. On $17^{\text {th }}$ day, the TMA-N was recorded to be $5.58 \mathrm{mg} \%$ and $3.66 \mathrm{mg} \%$ for TAP and TVP samples respectively. These findings are in agreement with the earlier reports on usage of vacuum packaging and treatment with various chemicals to preserve seafoods (Rajesh et al., 2002; Sawant, 2008 and Shakila et al., 2005).

The TVB-N was $8.92 \mathrm{mg} \%$ at the beginning of the storage in TAP and TVP samples, which gradually increased to $26.32 \mathrm{mg} \%$ and $21.77 \mathrm{mg} \%$ for TAP and TVP respectively on $17^{\text {th }}$ day of storage (Figure 3). Further on the $26^{\text {th }}$ day of storage the values rapidly increased and reached $30.01 \mathrm{mg} \%$ for TVP samples. The lower TVB$\mathrm{N}$ values were recorded in TVP sample during storage. The similar trend was observed by Rajesh et al. (2002) and Sawant (2008) during their studies on seafood quality.

A change in $\mathrm{pH}$ of fish muscle is usually a good index for quality assessment. In the present study, all the samples exhibited increase in $\mathrm{pH}$ during storage, from initial value of 7.11 for both TAP and TVP samples on 0 day, reaching to a value of 7.81 and 7.78 in TAP and TVP samples on $17^{\text {th }}$ and $27^{\text {th }}$ day respectively (Figure 4.). The study showed similar changes to those observed by Sawant (2008) and Shalini et al. (2000).

The initial AAN content was $18.46 \mathrm{mg} \%$ for both TAP and TVP samples (Figure 5). In case of TAP, it increased up to $38.14 \mathrm{mg} \%$ which in TVP increased up to $29.40 \mathrm{mg} \%$ on $27^{\text {th }}$ day. In the present study, the AAN showed a steady increase during the storage period of 26 days and reached $37.62 \mathrm{mg} \%$ on $26^{\text {th }}$ day. Decrease of AAN during ice storage is attributed to leaching out of soluble nitrogenous constituents (Govindan, 1972). In the present study, the TAP and TVP shrimp samples were not in indirect contact with ice or water. Because of impermeable flexible pouches and hermetic sealing, there was no leaching and AAN values showed only slow increase throughout the storage period. The changes observed were in agreement with the observations made by Rajesh et al. (2002) and Sawant (2008).

In the present study FFA increased from the initial level of $0.16 \%$ oleic acid in both TAP and TVP shrimp to 1.89 and $1.26 \%$ oleic acid on $17^{\text {th }}$ day of storage (Figure 6). The FFA value of TVP samples further increased and reached $1.74 \%$ on $26^{\text {th }}$ day of storage. In the present study, the FFA value increased significantly with storage period and the increase in TAP was found to be more than that in TVP samples. Similar results have also been reported previously by various researchers 
(Haung et al., 1991; Juvekar, 2007; Rajesh et al., 2002 and Shalini et al., 2000) during their work on seafood quality assessment.

\section{Changes in microbiological characteristics during ice storage}

During the present study, it was noticed that total plate count (TPC) showed a steady rise after a fall in count during experimental period (Figure 7). The count increased from an initial value of $4.08 \log _{\text {cfu g }}{ }^{-1}$ to 4.91 and $4.32 \log _{\mathrm{cfu}}{ }^{-1}$ for TAP and TVP samples respectively on $8^{\text {th }}$ day of storage. The gradual increase still continued and the total plate count recorded were 6.74 and $5.04 \log \mathrm{cfu} \mathrm{g}^{-1}$ for TAP and TVP samples respectively on the $17^{\text {th }}$ day. Further it was found that on $26^{\text {th }}$ day of storage, the value increased to $7.65 \log \mathrm{cfu} \mathrm{g}^{-1}$ in case of TVP samples. This increase in TPC with storage period was also observed previously in different seafoods during storage (Juvekar, 2007; Sawant, 2008 and Shalini et al., 2000).

Psychrotrophs are the major spoilage bacteria in foods stored at low temperatures. During the present study the psychrotrophic count increased from an initial value of $4.02 \log \mathrm{cfu} \mathrm{g}^{-1}$ to 4.95 and $4.47 \log \mathrm{cfu} \mathrm{g}^{-1}$ on $8^{\text {th }}$ day for TAP and TVP samples (Figure 8). The count further showed an increase to 7.04 and $5.76 \log$ cfu $\mathrm{g}^{-1}$ in case of TAP and TVP samples on $17^{\text {th }}$ day of storage. The psychrotrophic count of TVP samples further increased and reached $7.87 \log \mathrm{cfu} \mathrm{g}^{-1}$ on $26^{\text {th }}$ day of storage. A similar observations were also made by others (Juvekar, 2007; Sawant, 2008 and Shalini et al., 2000) during their studies.

In the present study, anaerobic counts could not be detected in fresh shrimp, but the counts increased up to 7.2 and $9.4 \mathrm{MPN} / \mathrm{g}$ in case of TAP and TVP samples respectively at the end of $8^{\text {th }}$ day of storage (Figure 9). Significant increase in anaerobe counts were observed i.e. 21 and $29 \mathrm{MPN} / \mathrm{g}$ in case of TAP and TVP samples respectively at the end of $17^{\text {th }}$ day of storage. In case of TVP samples the count further increased and reached $43 \mathrm{MPN} / \mathrm{g}$ on $26^{\text {th }}$ day of storage. The present observation is supported by observations made by others (Juvekar, 2007; Sawant, 2008 and Lyon and Reddmann, 2000).

The presence of Staphylococcus in fish is an indication of post harvest contamination. S. aureus was not detected in both TAP and TVP shrimp during entire storage period. The absence of S. aureus throughout the storage period was also reported by earlier researchers (Baug, 2008; Joseph et al., 1998 and Sanchez et al., 1994).

\section{Changes in sensory characteristics during ice storage}

In the present study melanosis was absent in both TAP and TVP samples during the entire storage in ice as observed for 27 days (Figure 10). Whereas samples treated with same concentration of sulfite and ice stored, showed melanosis on $11^{\text {th }}$ day. This extension in occurrence of melanosis in TAP and TVP samples might be due to the presence of sodium metabisulfite for whole storage period. However, in our previous studies it was observed that the amount of sulphite residues in treated 
and ice stored shrimps was reduced with storage period, which might be due to the effect of washing with ice melted water (Reddy and Patange, 2011).

It was reported that the combined effect of controlled atmosphere and melanosis inhibitors was used to delay blackspot development as compared to the shrimps stored in ice alone (Lyon and Reddmann, 2000; Reddy and Patange, 2011).

There was a significant decrease in sensory score in all the TAP and TVP samples during storage period (Figure 11). From the initial score of 9.75, the scores declined to 4.50 and 4.05 in case of TAP and TVP samples respectively on the day of rejection of $17^{\text {th }}$ and $25^{\text {th }}$ day of storage. The sensory score of 5 was observed on $16^{\text {th }}$ and $24^{\text {th }}$ day for TAP and TVP samples respectively. In the present study the shelf life showed significant difference between TAP and TVP samples which was 16 days and 24 days respectively. An extension of 8 days of shelf life was noticed due to packaging under inert condition. The present result is supported by identical observation recorded by earlier workers (Rajesh et al., 2002 and Shakila et al., 2005).

Form the study it was observed that a combination of anitmelanotic treatment and vacuum packaging extends the melanosis and increases the shelf life of tiger shrimp significantly. The samples were acceptable up to 16 days in TAP and 24 days in TVP samples. Extension of storage life in TAP and TVP samples were observed compared to treated shrimps without packaging, which had a shelf life of 14 days in our previous experiment (Reddy and Patange, 2011). This might be due to the presence of sulfites in packaged shrimps, and leaching out of sulfites with melting ice in shrimps without packaging. Extension of storage life in ice in vacuum-packed samples and samples treated with antimelanotic substances has been reported previously (Dalgaard et al., 1993; Mendonka et al., 1989 and Zhuang et al., 1996). In fact there is a very little literature available on combined effect of vacuum packaging and antimelanotic treatment on shrimp quality. It was also observed that the sensory scores correlated well with all other parameters estimated. The sensory scores decreased with the storage period and were acceptable up to 16 days and 24 days for TAP and TVP shrimp.

\section{CONCLUSION}

The use of combination of antimelanotic treatment and vacuum packaging was found to prolong the shelf life of tiger shrimp. The tiger shrimps were acceptable up to 16 days in TAP and 24 days in TVP samples. An extension of 8 days of shelf life was noticed due to packing under vacuum, compared to air-packed samples. An extension of 2 days of shelf life and complete absence of melanosis was noticed due to packing, compared to treated shrimps without packing. This indicates that even packing without vacuum after treatment with sulfite-based treatment $\left(30 \mathrm{~g} \mathrm{~kg}^{-1}\right)$ gives a good shelf life and preserves the quality in ice. It is concluded that a good quality and a shelf life up to 24 days in ice for fresh tiger shrimp can be obtained by packing under vacuum and a shelf life of up to 16 days by packing without vacuum after treating with $30 \mathrm{~g} \mathrm{~kg}^{-1}$ sulfites. 


\section{ACKNOWLEDGEMENTS}

The authors wish to express their thanks to Dr. Balasaheb Sawant Konkan Krishi Vidyapeeth, Dapoli for funding this work and Associate Dean, Fisheries College, Shirgaon for cooperation in carrying out this study.

\section{REFERENCES}

Antony, M. M., Jeyasekaran, G., Shakila, R.J. and Shanmugam, S.A. 2002. Bio-chemical quality of raw shrimps processed in seafood processing plants located in Tuticorin region of Tamil Nadu. Indian Journal of Food Science Technology, 39: 698-701

AOAC. 2000. Official Methods of Analysis of the Association of Official Analytical Chemists. $12^{\text {th }}$ ed. Washington DC

Baug, T. E. 2008. Application of hurdle technology in preparation of soft-moist prawns (Parapenaeopsis stylifera). M. Sc. (Fish.) diss. Dr. Balasaheb Sawant Konkan Krishi Vidyapeeth, Dapoli, Maharashtra

Benjakul, S. and Morrissey, T. 1997. Measurement of spoilage in fish. Journal of Fish Research Bd Canada, 3: 77-91

Chakrabarti, R. and Gupta, S.S. 1998. Studies on phenoloxidase activity and its sensitivity to metabisulfite in frozen Metapenaeus monoceros. Fishery Technology, 35: 30-33

Chakrabarti, R., Gupta, S.S., Rao, C.C.P. and Basu, S. 1992. Control of black discolouration in raw shrimps from tropical region. Fishery Technology, 29: 84-85

Conway, E.J. 1950. Micro diffusion Analysis and volumetric Error. Crosby, Lockwood, London

Dalgaard, P., Gram, L. and Huss, H.H. 1993. Spoilage and shelf life of cod fillets packed in vacuum or modified atmospheres. International Journal of Food Microbiology, 19: 283-294

FAO. 2009. Fishery and Aquaculture statistics 2007. Food and Agriculture Organization of the United Nations, Rome

Gomez-Guillen, M.C., Martinez-Alvarez, O., Liarnas, A. and Montero, P. 2005. Melanosis inhibition and $\mathrm{SO}_{2}$ residual levels in shrimps (Parapenaeus longirostris) after different sulfite-based treatments. Journal of Science Food and Agriculture, 85: 1143-1148

Govindan, T.K. 1972. Research on Freezing Preservation of Fish in India-a review. Indian Food Packer, 26: 52-59

Hanpongkittikun, A., Siripongvutikorn, S. and Cohen, D.L. 1995. Black tiger shrimp (Penaeus monodon) quality changes during iced storage. Asian Food Journal, 10: 125130

Haung, Y.W., Koehler, P.E., Eitenmiller, R.R. and Lillard, D.A. 1991. Effect of packaging on the storage quality of iced channel catfish. In proc. Fifteenth Annual Conference of tropical and subtropical Fisheries, Sea Grant, Florida University, Gainesville (USA)

Jeyasekaran, G., Maheswari, K., Shakila, R.J., Ganesan, P. and Akshmanan, R.L. 2004. Bacterial quality of vacuum packed Tuna (Euthynnus affinis) chunks stored under abused refrigerated temperatures. Asian Fish Science, 17: 217-227 
Joseph, J., Perigreen, P.A. and Iyer, T.S.G. 1998. Storage characteristics of cultured Penaeus indicus in ice and at ambient temperature. Journal of Food Protection, 35: 84-89

Juvekar, P.U. 2007. Effect of vacuum packaging on the shelf life of black king fish (Rachycentron canadus) flesh stored at low temperature. M.Sc. (Fish.) diss. Dr. Balasaheb Sawant Konkan Krishi Vidyapeeth, Dapoli, Maharashtra

Lopez-Caballero, M.E., Perez-Mateos, M., Borderias, J.A. and Montero, P. 2000. Extension of the shelf life of prawns (Penaeus japonicus) by vacuum packaging and highpressure treatment. Journal of Food Protection, 63: 1381-1388

Lyon, W.J. and Reddmann, C.S. 2000. Bacteria associated with processed crawfish and potential toxin production by Clostridium botulinum type $E$ in vacuum packaged and aerobically packaged crawfish tails. Journal of Food Protection, 63: 1687-1696

Martinez-Alvarez, O., Gomez-Guillen, M.C. and Montero, P. 2005. Role of sulfites and 4hexylresorcinol in microbial growth and melanosis prevention of deepwater pink shrimp (Parapenaeus longirostris) using a controlled atmosphere. Journal of Food Protection, 68: 98-104

Mendonca, A.F., Molins, R.A., Kraft, A.A. and Walker, H.W. 1989. Effect of potassium sorbate, sodium acetate and sodium chloride alone or in combination on shelf life of vacuum-packaged pork chops. Journal of Food Science, 54: 303-306

MPEDA. Marine Products Export Development Authority. 2010. http://www.mpeda.com.

Ogawa, M. 1987. Blackspot occurrence in lobsters and shrimp. Info fish Market Digest, 1: 4344

Perez-Alonso, F., Aubourg, S.P., Rodriguez, O. and Barros-Velazquez, J. 2004. Shelf life extension of Atlantic pomfret (Brama brama) fillets by packaging under a vacuumskin system. European Food Research Technology, 218: 313-317

Peryam, D.R. and Pligirms, F.J. 1957. Hedonic scale method of measuring food preferences. Food Technology, 2: 9-14

Rahaman, M., Yasmin, L., Kamal, Md., Mazid, MA. and Nazrul Islam, Md. 2001. Effect of delayed icing on the quality changes in brackish water shrimp Penaeus monodon during ice storage. Pakistan Journal of Biological Science, 4: 1390-1394

Rajesh, R., Ravi Shankar, C.N., Srinivasa Gopal, T.K. and Varma, P.R.G. 2002. Effect of vacuum packaging and sodium acetate on the shelf life of seer fish during iced storage. Packaging Technology Science, 15: 241-245

Reddy, S.V.K. and Patange, S.B. 2012. Melanosis Inhibition and $\mathrm{SO}_{2}$ Residual Levels in Farmed Tiger Shrimp (Penaeus Monodon) Following Different Sulfite Based Treatments. Journal of Aquatic Food Product Technology, 21: 330-337

Sanchez, G.L.S., Casales, M.R. and Yeannes, M.I. 1994. Preliminary development on intermediate moisture, pasteurized mackerel (Scomber japonicus marplantensis) chunks. Journal of Science Food and Agriculture, 64: 199-204

Sawant, S.S. 2008. Effect of vacuum packaging on the shelf life of the chilled and frozen stored farmed shrimp (Penaeus monodon). M.Sc. (Fish.) diss. Dr. Balasaheb Sawant Konkan Krishi Vidyapeeth, Dapoli, Maharashtra

Shakila, R.J., Jeyasekaran, G. and Vijayalakshmi, S.K. 2005. Effect of vacuum packaging on the quality characteristics of seer fish(Scomberomorus commersonii) chunks during 
refrigerated storage. Journal of Food Science and Technology, 42: 432-443

Shalini, R., Jasmine, G.I., Shanmugam, S.A. and Ramkumar, K. 2000. Sodium acetate and vacuum packaging to improve shelf life of refrigerated Lethrinus lentjan fillets. Fishery Technology, 37: 8-14

Smith, L.G. 1980. Cost of controlling 'blackspot' repaid in better prawn prices. Australian Fisheries, 01: 49-53

Tomlinson, L.A. 1995. Bacteriological Analytical Manual. $18^{\text {th }}$ ed. AOAC: Washington DC.

Zhuang, R.Y., Haung, Y.W. and Beuchat, L.R. 1996. Quality changes during refrigerated storage of packaged shrimp and cat fish fillets treated with sodium acetate, sodium lactate or propyl gallate. Journal of Food Science, 61: 241-244 
Table 1: Physical properties of the packaging material

*Tensile strength

Machine direction (MD)

$363 \mathrm{Kg} / \mathrm{cm}^{2}$

Cross-direction (CD)

$349 \mathrm{Kg} / \mathrm{cm}^{2}$

*Elongation at break (MD)

$80 \%$

Elongation at break (CD)

$80 \%$

*Heat seal strength (MD)

$249 \mathrm{Kg} / \mathrm{cm}^{2}$

Heat seal strength (CD)

$194 \mathrm{Kg} / \mathrm{cm}^{2}$

Water vapour transmission rate

$3.62 \mathrm{~g} / \mathrm{m}^{2} / 24 \mathrm{~h}$ at $37^{\circ} \mathrm{C}$ at $90+2 \%$

(as per ISI 060, Part II, 1960)

$\mathrm{RH}$

Oxygen transmission rate (OTR) (as per ASTM 1975)

65

$\mathrm{ml} / \mathrm{m}^{2} /$ atmospher $\mathrm{e} / 24 \mathrm{~h} /$ room temperature (28$\left.32^{\circ} \mathrm{C}\right)$

*As per IS2508, 1984.

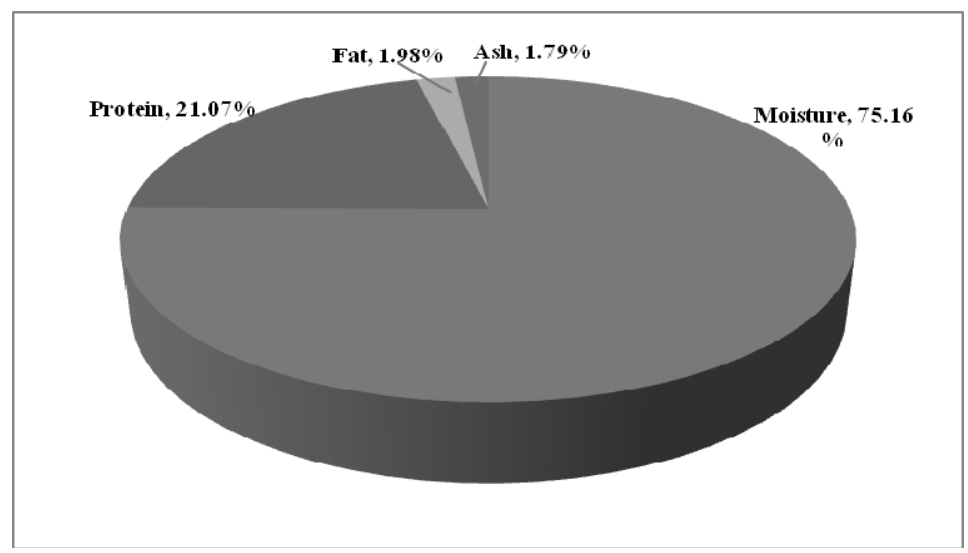

Figure 1: Proximate composition of fresh tiger shrimp (Penaeus monodon) 


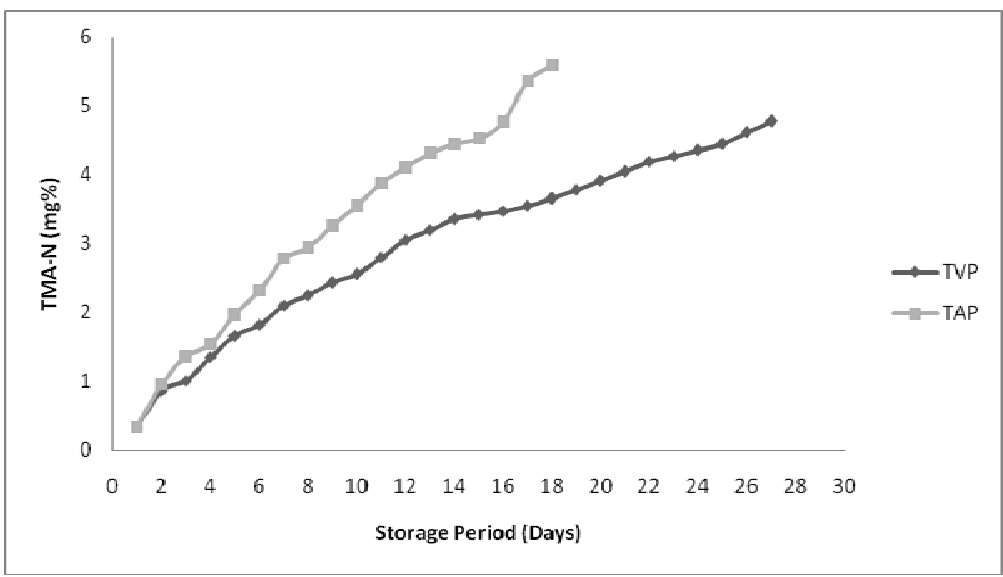

Figure 2: Changes in TMA-N (mg\%) content in tiger shrimp during ice storage

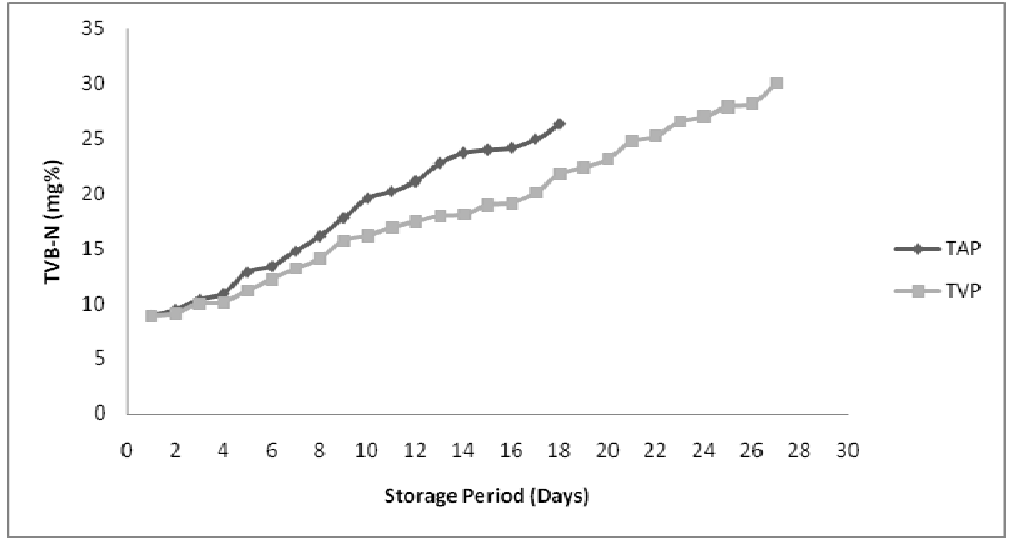

Figure 3: Changes in TVB-N (mg\%) content in tiger shrimp during ice storage

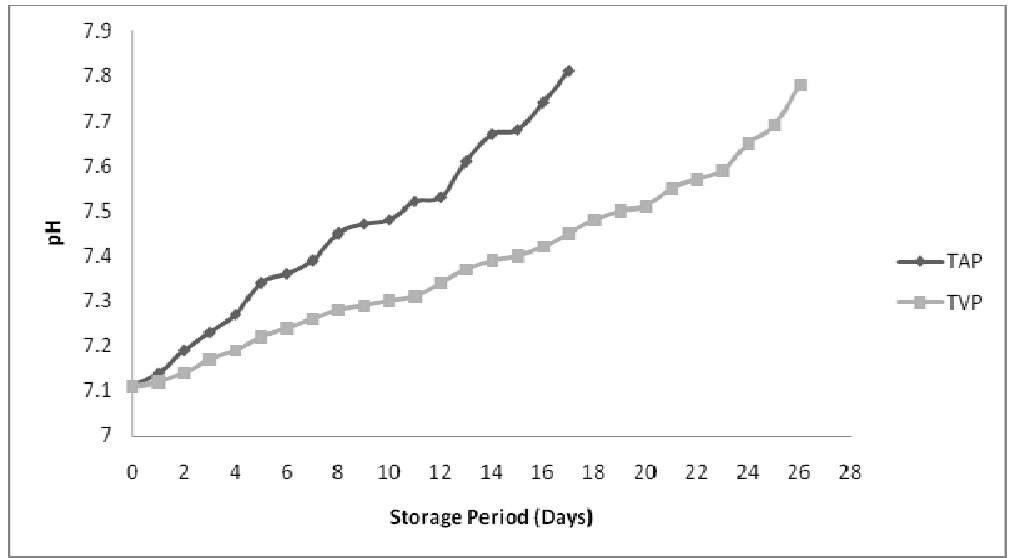

Figure 4: Changes in $\mathrm{pH}$ in tiger shrimp during ice storage 


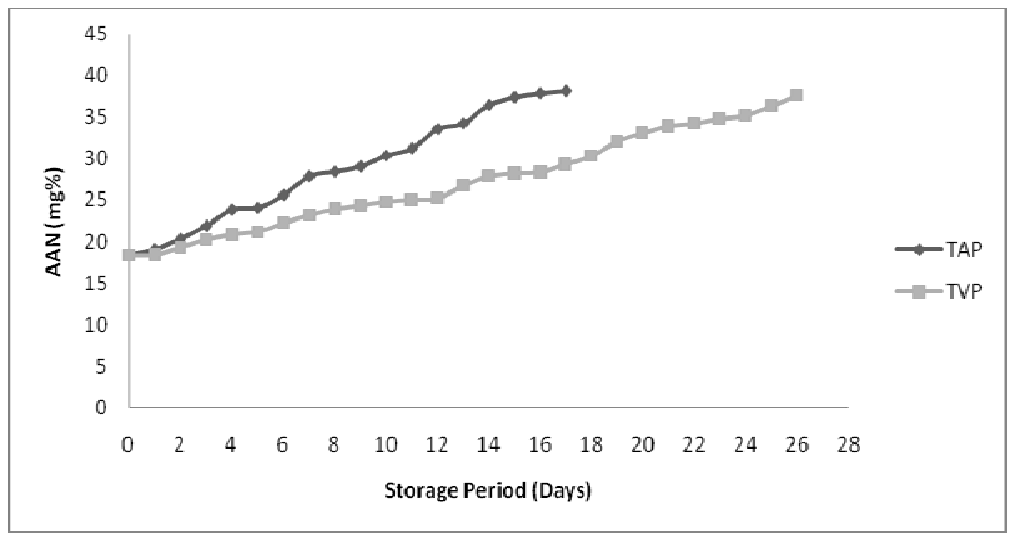

Figure 5: Changes in AAN (mg\%) content in tiger shrimp during ice storage

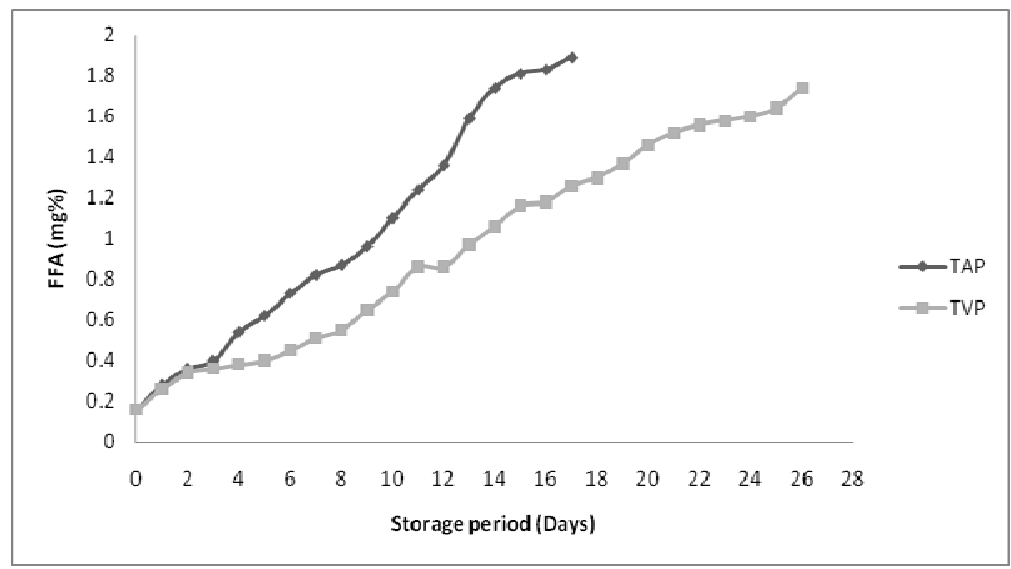

Figure 6: Changes in FFA (Oleic acid \%) content in tiger shrimp during ice storage

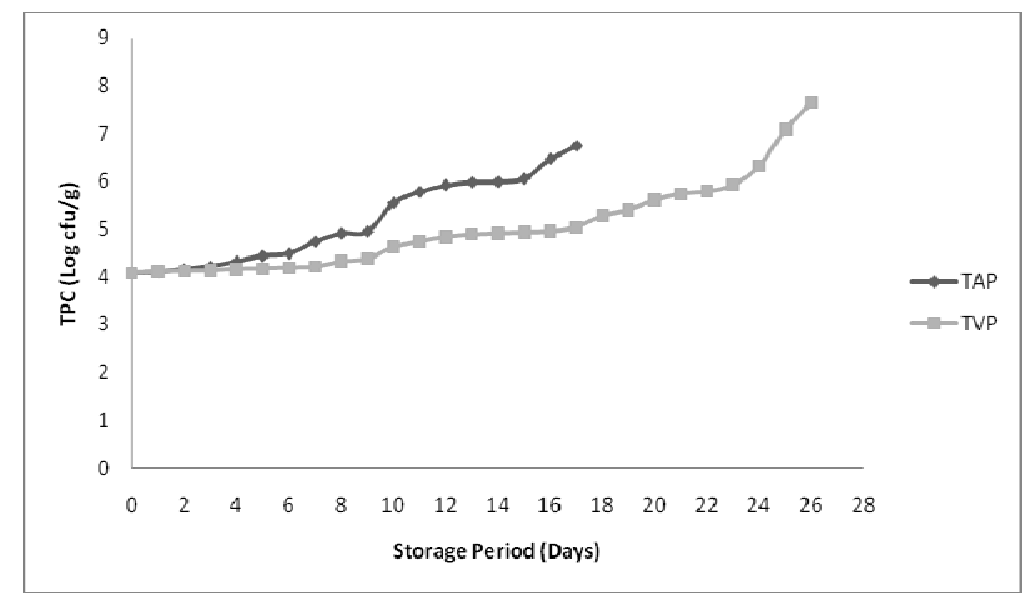

Figure 7: Changes in TPC $\left(\log \mathrm{cfu} \mathrm{g}^{-1}\right)$ in tiger shrimp during ice storage 


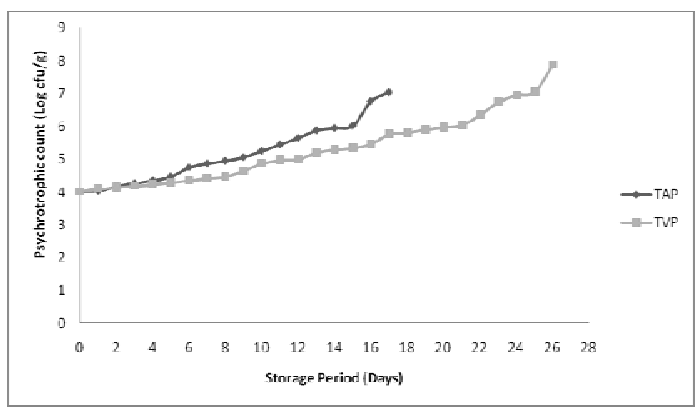

Figure 8: Changes in psychrotrophic count $\left(\log \mathrm{cfu} \mathrm{g}^{-1}\right)$ in tiger shrimp during ice storage

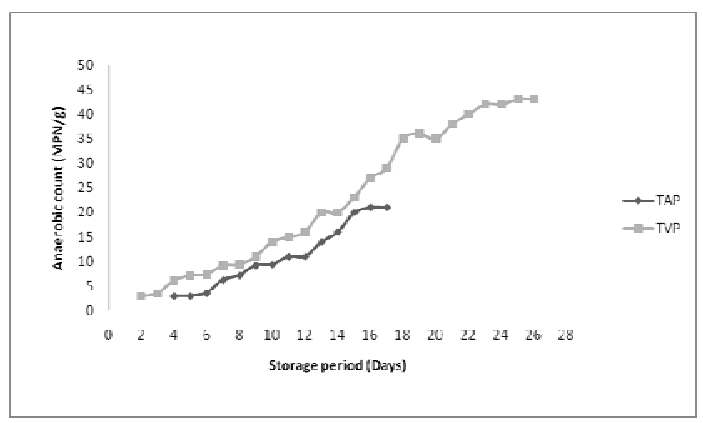

Figure 9: Changes in anaerobic count (MPN g $\left.{ }^{-1}\right)$ in tiger shrimp during ice storage

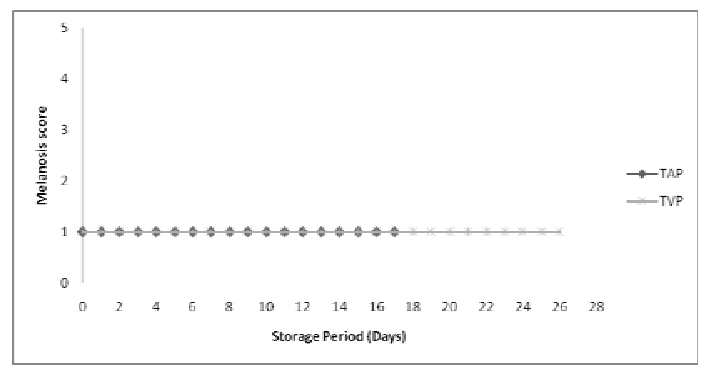

Figure 10: Changes in melanosis score in tiger shrimp during ice storage

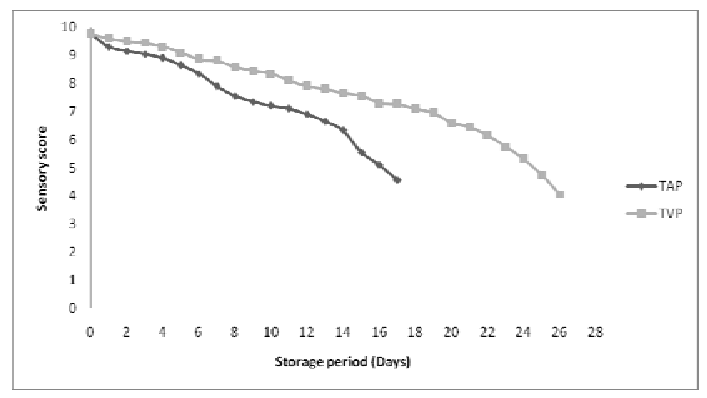

Figure 11: Changes in sensory score in tiger shrimp during ice storage 